\title{
A Window Seat on American Politics: Reflections on the GMFUS/APSA Congressional Fellowship
}

Sebastian Bruns, APSA Congressional Fellowship Program, 2010

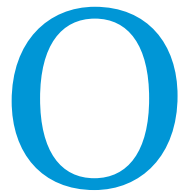

$\mathrm{n}$ a foggy Monday morning in late September 2010 in Kiel, Germany, I received a phone call from Berlin. "Do you have any plans for November through summer of next year?" the voice inquired. One of the two German Marshall Fund congressional fellows for the 2010-2011 round had suddenly dropped out and a replacement was needed. The call came five months after I had been initially rejected for the fellowship, and while my life had certainly moved on (I had begun work on my PhD dissertation at the University of Kiel and had expected to stay in Northern Germany for two or three years), I quickly regained my composure, asked for time to discuss this with my dissertation director as well as with my parents, and shortly thereafter accepted the selection. Exactly how I managed to cram the amount of work required for moving overseas into four weeks instead of the usual four to six months remains blurry. Eventually, however, I was able to tie up the loose ends in Germany, get the appropriate work visa for the United States, and even participate in a prestigious, long-planned naval reserve exercise that the German Navy's chief of naval operations had invited me to attend.

The latter organization relates to my professional background, sparked by an internship at the Naval History and Heritage Command (Washington, DC) in 2005. I graduated with an MA in North American Studies in 2007 (University of Bonn). After working six months for the Mayor of Bonn, a first exposure to government, procedures, and protocol, I was employed at a Hamburg-based public policy institute as an analyst and lecturer. As such, I was responsible for their maritime security portfolio, including numerous briefings, publications, and lectures for the German military and other audiences, specifically on the re-emerging threat of piracy off the coast of Somalia. In early 2010, parallel to taking on my $\mathrm{PhD}$ dissertation on US naval and maritime strategy, I significantly deepened my expertise by freelancing for a Danish maritime security company. Although at age $28 \mathrm{I}$ was not as advanced in my career as other fellows from my class were, security policy work inside and outside the Ivory Tower led me to consider myself well-equipped for a position in the "engine room" of US politics, working on issues broadly related to my expertise. Little did I know that with what I thought was an impressive background, I would have a devil of a time securing a slot on a congressional staff, even after being accepted as a GMFUS/APSA fellow. The fellowship only secures

Sebastian Bruns, a PhD candidate at the University of Kiel and a maritime security analyst, participated in the APSA Congressional Fellowship Program 2010-11. He can be reached at Sebastian-Bruns@web.de. you a stipend; finding an actual job on Capitol Hill is up to the individual.

\section{ORIENTATION}

"Richard Nixon had to burglarize the Watergate to lose this many seats in the House of Representatives!" said Scott Lilly. A senior fellow at the Center for American Progress, he was one of the invited speakers during our orientation. My classmates and I arrived in Washington at one of the most exciting times in recent memory, and certainly during a period of great political upheaval caused by the November 2010 midterm elections. A political landslide unseated many Democrats and swept many young Republicans into offices. This changing of the guard compelled me to completely rethink the list of offices to which I had hoped to apply. In terms of the right time to secure a position-even for a motivated, efficient, reliable fellow completely free of charge to the office-our timing was unfortunate. Many congressmen with vast military and security policy expertise were suddenly no longer viable options. These included Vice Admiral (ret.) Joe Sestak (Rep., D-PA), Glenn Nye (Rep., D-VA), Gene Taylor (Rep., D-MS), and Ike Skelton (Rep., D-MO).

Many of the congressional offices suddenly became lame-duck organizations tasked with pulling the plug on their operations and closing down by Christmas 2010, and the new offices quickly needed to set up shop in the nation's capital, hire staff, and organize. The high rate of employee turnover and uncertainty-that is, members' committee assignments, ambiguity about the pressing legislative priorities for 2011, and even points of contact to send applications combined with the somewhat unfavorable conditions pertaining to my own situation. A foreign national without a security clearance aspiring to work on issues related to US national security, international relations, and foreign policy must have raised more than a few eyebrows, and inevitably led to many rejections for interviews.

Toward the end of the orientation period in mid-December, my frustration began. Fifteen applications mailed in December yielded three negative responses. Twelve other offices did not respond at all. By mid-January 2011-a time when I initially considered the starting point for my work for Congress-I had sent 34 applications, again to no avail. By then, a targeted approach to members' offices dealing with maritime and defense issues gave way to a "full broadside" of applications aimed at offices with even the remotest connection to Germany or international relations. By January 25, I sent 68 applications, and I had long given up on the idea to work on issues of my choice; by February 1, the number of applications stood at 76 ! Efforts by many individuals, including some of my former US Navy colleagues, to secure a 
position outside of the legislative branch to tide me over until something on the Hill could be secured also bore no fruit. I remained Washington's best-paid unemployed person while my fellow APSA congressional fellows started working for their respective offices. The handful of job interviews that I did manage to secure did not yield anything other than general reluctance and somewhat esoteric questions. My favorite remains the interviewer from a Democrat Senate office, who asked "Which one do you like more: Politics or policy?" and "Where do you see yourself 30 years from now?" A final, desperate attempt for a job on the Hill came right after the announcement of the committee assignments for the Armed Services Committees, raising the number of my applications to 82 . And indeed, after I was invited to a House of Representatives' freshman office for a couple of interviews, the "fourth quarter miracle" occurred.

\section{SECURING A POSITION}

Although I was nervous, I instantly felt that this office could be a decent fit after meeting the newly appointed legislative director (LD), the only staffer with notable Hill experience. The congressman had relationships to Germany through his military service and academic career. His district even features a German heritage "Strassenfest" main street festival. Moreover, Rep. Todd Young, an attorney from Bloomington (Ind.), who separated from the US staff who are protective of their turf and reluctant to delegate substantive work to fellows.

\section{"LIVING THE DREAM"}

With the office already fully underway on its steep learning curve, I was thrown into the deep end of daily business. Thankfully, my background (having closely studied the US political system for years) and the intensive APSA orientation program, especially the Congressional Research Service (CRS) legislative process sessions, had well equipped me for the challenge. In my first week alone, I prepared briefing material for the congressman for HASC hearings on various topics, drafted response letters to constituents on defense and international relations matters, met with industry lobbyists, assembled a reading list of articles and books on sea power and maritime strategy, and attended several briefings for congressional staff. These sorts of activities soon became a fixture of my work on the Hill.

The LD and I quickly decided that it would not make much sense to apply for a security clearance of my own. The fellowship would be over before the background investigation would be completed. In hindsight, it was the right decision. On only a handful of occasions was I excluded from selected hearings or briefings that dealt with classified information. "Off the record" meetings were always handled with the strictest professionalism. Security

\section{My background (having closely studied the US political system for years) and the intensive APSA orientation program, especially the Congressional Research Service (CRS) legislative process sessions, had well equipped me for the challenge.}

Marine Corps as captain after serving his commitment, graduated from the US Naval Academy. He sits on the House Armed Services Committee (HASC) and the House Budget Committee, two of the most exciting working groups in the 112th Congress. On the HASC, he is also on the Subcommittee on Seapower and Expeditionary Forces. Therefore, I was thrilled when the office offered me a position, and I began work on February 24, 2011after an almost four-month-long job search.

Although Indiana's gth congressional district is no stranger to APSA congressional fellows (long-time incumbent Rep. Lee Hamilton (D) is featured as a proponent of the program on the APSA Congressional Fellowship Program's website), this selection still stood out in a number of ways. Despite the challenges outlined above, I was tasked mainly with defense issues, working with the LD on all issues pertaining to HASC. I was also the only congressional fellow from my class to secure a position with a newly elected Republican office. Since 1953, APSA Congressional Fellowship Program has an impressive trackrecord of bringing midcareer academics to Washington. Although the balance is changing, over the years the APSA Congressional Fellowship Program participants have tended to choose offices held by senior members of the Democrat Party. I ended up finding an advantage in my new freshman office. I was instantly involved in daily and weekly deliberations on almost all issues coming across the congressman's desk. It is my understanding that this was different from some of the more established congressional offices where fellows often encounter long-entrenched was never once compromised, and I am eternally grateful for the opportunity to work on matters pertaining to defense and the military of the United States. For me "living the dream," an expression very often used in a casual and satirical sense by many on the Hill, was actually true.

Almost every day I experienced something extraordinarily interesting, fulfilling, or entertaining. In March, I was given the opportunity to witness Australian prime minister Julia Gillard's remarks before a Joint Session of Congress from the House floor; write a memo for my congressman on why expeditionary fighting vehicles could be useful for amphibious warfare; and "fly" the F-35 Joint Strike Fighter at Lockheed Martin's training simulator. The following months saw similar action. Some snapshots: In April, I sat right behind then-secretary of defense Robert Gates and then-chairman of the joint chiefs of staff Admiral Mike Mullen during a heated HASC hearing on operations against Libya (prompting a running gag at the office about unintentional media appearances). Together with my fellow German Marshall Fund fellow Dr. René Wildangel, I was also interviewed for a story in the daily "The Hill." In May, I attended a luncheon hosted by the German-American Business Council in honor of Congressman Young with him as a keynote speaker. In June, I organized a briefing for congressional staff on Somali pirate leaders. In July, we commenced work on the Electronic Warfare Working Group (EWWG) and on the path forward regarding the Quadrennial Defense Review (QDR). In August, I interviewed one of the primary authors of the current US maritime strategy. 
Even regular occurrences such as the weekly legislative staff meetings with the congressman or the "pizza briefs" by the House of Representatives US Navy Liaison Office on various maritime and naval subjects were, more often than not, fascinating. I also found work with Indiana constituents to be one of the highlights of the experience. By welcoming citizens of the state to the office, and reading the letters they sent to the congressman, I gained a better understanding of my adopted home-state (indeed, I was labeled an "honorary Hoosier" during a visit to Indiana). Preparing the requests for the National Defense Authorization Act (NDAA) for fiscal year 2012 with Congressman Young and the LD also gave me insights into the legislative priorities and political characteristics of southern Indiana. I learned firsthand about the process of defense spending, which is an invaluable experience in support of my PhD dissertation. Shepherding an issue such as NDAA from start to finish (16.5 hours of mark-up debate lasting until 2.30 a.m. on May 12, 2011) was a most insightful event.

\section{THE SOMBER SIDE OF POLITICS AND POLICIES}

At the same time, I saw the immense challenges that Congress confronts when trying to craft policy. This held true for external and domestic politics. The March 11, 2011, Japanese earthquake and resulting nuclear disaster brought back memories of the 1986 Chernobyl catastrophe, and while my own government completely reversed its course on nuclear energy and decided to shut off all reactors, the events in Japan had almost no impact on US energy policy.

The revolution in Libya was another pivotal issue. When longtime dictator Muammar Gaddafi prepared to crush his people's uprising by force, NATO air strikes enforced a no-fly zone. NATO's decision to intervene was questioned by many, including (and unfortunately very prominently) my own government. The successful results of the operations have since proved the naysayers wrong. In the United States, what surprised me was the dwindling public support, especially among conservatives, for a robust American foreign policy, particularly in an era of fiscal austerity.

The one issue that did not go away during the fellowship year was the matter of future government resourcing. Several times during 2011, continuing resolutions and last-ditch efforts to contain the debt crisis left the government in limbo and had staff and politicians rushing to emergency meetings to avoid a government shutdown. To be blunt: this is certainly no way to run a country, especially one burdened with so many responsibilities as the United States. Then again, these examples were among some of the most sobering and useful learning experiences during my time in Washington.

\section{FELLOWSHIP BENEFITS}

The opportunities or "perks" offered by the APSA Congressional Fellowship Program are numerous, too. Hosting our Canadian counterparts to Washington, DC, and spending a week with them in Canada was an enriching experience; a trip to the congressional district (which, in my case, contained unique experiences such as visiting a weapons proving ground, a veterans' town hall meeting with the congressman, and a visit to a state-of-the-art jet fighter engine plant where the company's vice-president flew in from
Washington to personally welcome me to the factory) yielded some very useful insights on southern Indiana and its economic and political interests. Briefings during a day-trip to Maryland's state capital, Annapolis, provided insights on state politics versus the federal level. Biweekly Friday afternoon "Wilson Seminars" in the Capitol offered an opportunity to broaden our horizon beyond legislative concerns and a chance to chat with other APSA fellows.

Moreover, the "open sesame" functions of the Congressional ID allowed for countless interesting experiences (while strictly adhering to the Ethics Committee rules and regulations) both on and off the Hill. From joining a "congressional ride-along" on a fire truck in Northwest Washington; being part of a piracy panel at a conservative think tank; getting a "shout-out" at high-level conferences; meeting senior military and civilian leaders from around the country; visiting the Pentagon for official business; and having preferential treatment in the waiting line for the selfguided White House tour to attending get-togethers with the staff of a House leadership office and witnessing the informal, very relaxed atmosphere in HASC subcommittee mark-ups for NDAA FY 12, it was difficult not to feel like a kid in a candy store. One of the most interesting job perks was the opportunity to attend a staff delegation (STAFFDEL) hosted by the US Army at Fort Polk, Louisiana. In the blistering Southern heat ("Above all: Hydrate! Hydrate! Hydrate!"), we were introduced to all that the Army can and will do. We even underwent some military schooling of our own, including driving a mine resistant ambush protected vehicle (MRAP), Afghan cultural training, and weapons handling (with blank ammunition). I will certainly never forget the opportunity to fly in a Blackhawk and a Chinook helicopter! Indeed, I did not expect any of these things to happen in early February 2011, let alone in September 2010: Talk about going full circle.

\section{LOOKING BACK}

A final issue that I always value very highly is my obligation as a representative of my home country. Whether in private or public capacity, I aim to foster improved transatlantic relations. The vivid German community in Washington and the newly founded German-American caucus to which Rep. Young became a member worked hard throughout the year to advance Germany's image on and off the Hill. The fact that there are few German researchers on US national security and maritime matters, let alone foreign staffers in aspiring congressional offices, allowed me to gain the full attention of my counterparts.

After an office remodeling in June 2011, my desk was moved to a window in our office on the 7 th floor of the Longworth House Office Building. This allowed me a terrific view of the Washington Monument. Figuratively speaking, the fellowship was that: A window-seat into American politics that I will forever cherish. I am very thankful to the German Marshall Fund and the APSA Congressional Fellowship Program for this opportunity, and grateful to the Office of IN-og for allowing me to work for them. It is very unfortunate that the German Marshall Fund has decided to bring its support of the APSA Congressional Fellowship Program to a close, following the 2011-2012 cycle. I close by recommending to future APSA fellows: Be bold, follow your ideals, and consider junior offices for your fellowship. The fellowship is what you make of it. - 